\title{
Gene actions involved in the inheritance of yield related traits in bread wheat (Triticum aestivum L.)
}

\author{
Natasa Ljubičić ${ }^{\star *}$, Sofija Petrović1, Miodrag Dimitrijević1, Nikola Hristov² \\ ${ }^{1}$ Faculty of Agriculture, University of Novi Sad, Sq. D. Obradovića, Novi Sad, Serbia, ${ }^{2}$ nstitute of Field and Vegetable Crops, Maksima Gorkog, \\ Novi Sad, Serbia
}

\section{A B S T R A C T}

\begin{abstract}
One of the successful ways in breeding program and determining breeding methodology is information about the type of gene action involved in the inheritance of a character in different wheat generations. The objective of this study was to estimate gene effects for grain yield traits in wheat (Triticum estivum L.) in four selected crosses, involving five parents, their first and second filial generations $\left(F_{1}, F_{2}\right)$ and first back crosses generations $\left(\mathrm{BC}_{1}\right)$. The gene effects were estimated on the basis of generation mean analysis, using an additivedominant model with three and six-parameters. The adequacy of the additive-dominance model with three-parameters was tested using the Scaling test and Chi-square $(\chi 2)$ test. The significant Scaling tests and Joint-scaling test indicated the presence of digenic epistasis for the most of studied traits. The application of six-parameter models revealed that genetic effects for certain traits depended on the particular cross and differed on an overall basis. The significant type of non-allelic interactions which was observed in most of cross combinations was additive $\times$ additive (i) and dominance $\times$ dominance (I). Duplicate gene interactions were also observed, which are quite difficult to exploit in breeding programs. From these observations it is suggested that selection for the improvement of some traits should be effective in advanced segregating generations due to non-allelic gene interaction, while in cross combination where epistasis did not make a significant contribution among the generation means, selection in early segregating generations would be effective.
\end{abstract}

Keywords: Gene effects; Interactions; Wheat; Yield traits

\section{INTRODUCTION}

Wheat is one of the world's most important staple crops and provides $20 \%$ of the food calories and similar proportion of daily protein to the world's population (Reynolds and Braun, 2013). Global demand for wheat continues to increase at an annual rate of $1.6 \%$ and certain estimates indicate that $60 \%$ more wheat will be needed by the year 2050 (WHEAT, 2014; Singh et al., 2015). Wheat production can be increased either by bringing more area under cultivation or by developing new, high yielding cultivars. Obtaining wheat cultivars with high genetic potential for grain yield, as well as good quality of wheat are the main priority of breeding programs (Petrović et al., 2012a; Petrović et al., 2012b). Given that grain yield is a complex trait, it includes many quantitative components and has a polygenic inheritance, breeders normally use yield components to improve the grain yield, despite the fact that these components compensate each other in practice and an increase in one component causes a decrease in the other component (Foroozanfar and Zeynali, 2013; Ljubičić et al., 2014). As an efficient breeding program requires understanding of the nature, magnitude of gene effects and their contribution to the inheritance of the yield and yield components, in order to increase the genetic potential of wheat, numerous different analysis methods have been developed. Among these, plant breeders often use generation mean analysis to get information about gene action which is controlling the traits. The greatest contribution of this analysis lies in the ability to estimate epistatic gene effects such as additive $\times$ additive (i), dominance $\times$ dominance $(\mathrm{j})$ and additive $\times$ dominance (l) effects (Singh and Singh, 1992). Gene effects in different wheat crosses have been investigated by several researchers (Ojaghi and Akhundova, 2010; Erkul et al., 2010; Tonk et al., 2011; Kumar et al., 2013; Ljubičić et al., 2015). They revealed that additive, dominance and epistatic gene effects were involved in the inheritance of yield and yield components. Since that improvement of grain yield, as well as good quality of wheat are the main

\footnotetext{
${ }^{*}$ Corresponding author:

Nataša Ljubičić, PhD, Faculty of Agriculture, University of Novi Sad, Sq. D. Obradovića 8, 21000 Novi Sad, Serbia.

E-mail: ljubicic.natasa@gmail.com
} 
priorities of wheat breeding programs, in an effort to meet these demands, parental components were selected in this investigation. Winter wheat genotypes Pobeda, Renesansa, Pesma and Sara have been leading varieties in Serbian wheat production with high grain yield, while genotype Partizanka possess excellent bread quality, higher plant height and significantly lower grain yield potential. The results of these crossing combinations could be providing usable genetic variability for grain yield and grain quality improvement. Therefore, the present study was carried out to obtain information about the types of gene effects for four important grain yield components in order to enhance breeding efficiency in four perspective bread wheat crosses.

\section{MATERIALS AND METHODS}

This study was carried out at the experimental trial field of the Institute of Field and Vegetable Crops in Novi Sad, Serbia, during the three successive growing seasons of 2009/2010, 2010/2011 and 2011/2012. The experimental material in the study was comprised of five winter wheat varieties namely, Pobeda (high yielding), Renesansa (high yielding), Sara (high yielding), Pesma (high yielding) and Partizanka (excellent bread quality and lower yielding), Table 1.

Each of high yielding wheat genotypes (Pobeda, Renesansa, Pesma and Sara) were crossed with genotype Partizanka (excellent bread quality). Five basic generations were obtained: parent cultivars $\left(\mathrm{P}_{1}, \mathrm{P}_{2}\right)$, first and second filial generations $\left(\mathrm{F}_{1}, \mathrm{~F}_{2}\right)$ and first backcrosses $\left(\mathrm{BC}_{1}\right)$ of four cross combinations (Pobeda/Partizanka, Renesansa/ Partizanka, Sara/Partizanka and Partizanka/Pesma). The trial was sown in a randomized block design, with three replications. The cultivars were sown in $2 \mathrm{~m}$ long rows with $20 \mathrm{~cm}$ of inter-row spacing and $10 \mathrm{~cm}$ spacing

\begin{tabular}{|c|c|c|c|}
\hline Cross & Parent & Pedigree & Origin \\
\hline \multicolumn{4}{|l|}{ Cross 1} \\
\hline $\begin{array}{c}\mathrm{P}_{1}^{\mathrm{b}} \\
\mathrm{P}_{2} \mathrm{c} \\
\text { Cross } 2\end{array}$ & $\begin{array}{l}\text { Pobeda } \\
\text { Parizanka }\end{array}$ & $\begin{array}{l}\text { Sremica/Balkan } \\
\text { Bezostaja 1/NS } 116\end{array}$ & IFVCNS $^{a}$ \\
\hline $\begin{array}{c}P_{1} \\
P_{2} \\
\text { Cross } 3\end{array}$ & $\begin{array}{l}\text { Renesansa } \\
\text { Partizanka }\end{array}$ & $\begin{array}{l}\text { Jugoslavija/NS55-25 } \\
\text { Bezostaja 1/NS } 116\end{array}$ & IFVCNS \\
\hline $\begin{array}{c}\mathrm{P}_{1} \\
\mathrm{P}_{2} \\
\text { Cross 4 }\end{array}$ & $\begin{array}{l}\text { Sara } \\
\text { Partizanka }\end{array}$ & $\begin{array}{l}\text { Partizanka/Jedina//Evropa } \\
\text { Bezostaja 1/NS } 116\end{array}$ & IFVCNS \\
\hline $\begin{array}{l}\mathrm{P}_{1} \\
\mathrm{P}_{2}\end{array}$ & $\begin{array}{l}\text { Partizanka } \\
\text { Pesma }\end{array}$ & $\begin{array}{l}\text { Bezostaja 1/NS } 116 \\
\text { NS51-37/Balkan }\end{array}$ & IFVCNS \\
\hline
\end{tabular}

alFVCNS: Institute of field and vegetable crops, Novi sad, Serbia; ${ }^{b} \mathrm{P}_{1}$ : First parental lines, ${ }^{\mathrm{C}} \mathrm{P}_{2}$ : Second parental lines between plants in the row. The main sample consisted of 10 plants per replication. At the stage of full maturity grain yield components, namely the plant height, spike length, number of grains per spike and grain weight per spike $(\mathrm{g})$ was analyzed. The gene effects of the grain yield components of wheat, were estimated for each cross combination by Generation mean analysis $\left(\mathrm{P}_{1}\right.$, $\mathrm{P}_{2}, \mathrm{~F}_{1}, \mathrm{~F}_{2}$ and $\mathrm{BC}_{1}$ ), using an additive-dominance model of three-parameters (Mather, 1949). The adequacy of the additive-dominance model with three-parameters was tested using the Scaling test (A, B and C) and Chisquare $\left(\chi^{2}\right)$ test. The simple genetic model $(\mathrm{m}, \mathrm{d}$ and h) was applied when epistasis was absent, whereas in the presence of non-allelic interaction the analysis was proceeded to estimate the interaction types involved using the six-parameter genetic model i.e. ( $\mathrm{m}, \mathrm{d}, \mathrm{h}, \mathrm{i}, \mathrm{j}$ and $\mathrm{l}$ ) according to Mather and Jinks (1982). All the statistical analysis was carried out using OPSTAT statistical software. According to the methodology of Hayman (1960) the following notation for gene effects were used, where $(\mathrm{m})$ represents mean effect, (d) additive gene effects, (h) dominance gene effects, (i) additive $\times$ additive epistatic effects, (j) additive $\times$ dominance epistatic effects and (l) dominance $\times$ dominance epistatic gene effects. The type of epistasis was determined only when dominance (h) and dominance $\times$ dominance (l) effects were significant. When these effects had the same sign, the type of epistasis was complementary, while different signs indicated duplicate epistasis (Kearsey and Pooni, 1996).

\section{RESULTS}

The overall mean values and their standard errors for the analyzed traits of different generations of the four winter wheat crosses are presented in Table 2. It was observed significant differences among the five generations $\left(\mathrm{P}_{1}\right.$, $\mathrm{P}_{2}, \mathrm{~F}_{1}, \mathrm{~F}_{2}$, and $\mathrm{BC}_{1}$ ) and the greatest values for all studied traits varied from one cross to another on overall basis. With regard to the trait plant height, the greatest value was observed in the second filial generations $\left(\mathrm{F}_{2}\right)$ in cross combination Sara/Partizanka $(90.5 \mathrm{~cm})$, while the lowest value was observed in the first backcross generation $\left(\mathrm{BC}_{1}\right)$ in cross combination Renesansa/Partizanka $(72.3 \mathrm{~cm})$. With regard to the trait number of grains per spike, the greatest value was observed in the first backcross generation $\left(\mathrm{BC}_{1}\right)$ in cross combination Sara/Partizanka (48.7), while the lowest value was observed in the second filial generations $\left(\mathrm{F}_{2}\right)$ in cross combination Pobeda/ Partizanka (34.3). With regard to the trait grain weight per spike, the greatest value was observed in the first filial generation $\left(\mathrm{F}_{1}\right)$ in cross combination Sara/Partizanka $(2.0 \mathrm{~g})$, while the lowest value was observed in the second filial generation $\left(\mathrm{F}_{2}\right)$ in cross combination Partizanka/ 
Table 2: Generation means and standard errors for five generations $\left(P_{1}, P_{2}, F_{1}, F_{2}\right.$, and $\left.B C_{1}\right)$ in four winter wheat crosses for four yield contributing traits

\begin{tabular}{|c|c|c|c|c|}
\hline & \multicolumn{4}{|c|}{ Plant height $(\mathrm{cm})$} \\
\hline \multirow{3}{*}{$\begin{array}{l}\text { Trait } \\
\text { Generation }\end{array}$} & \multicolumn{4}{|c|}{ Cross combination } \\
\hline & $\begin{array}{l}\text { Pobeda/ } \\
\text { partizanka }\end{array}$ & $\begin{array}{l}\text { Renesansa/ } \\
\text { partizanka }\end{array}$ & $\begin{array}{c}\text { Sara/ } \\
\text { partizanka }\end{array}$ & $\begin{array}{c}\text { Partizanka/ } \\
\text { pesma }\end{array}$ \\
\hline & Mean $\pm S E^{f}$ & Mean \pm SE & Mean \pm SE & Mean \pm SE \\
\hline$P_{1}^{a}$ & $74.3 \pm 1.81$ & $77.1 \pm 1.81$ & $74.7 \pm 2.10$ & $79.3 \pm 2.21$ \\
\hline $\mathrm{F}_{1}{ }^{\mathrm{b}}$ & $77.6 \pm 2.22$ & $74.8 \pm 2.12$ & $77.7 \pm 1.71$ & $84.6 \pm 2.10$ \\
\hline $\mathrm{F}_{2}^{\mathrm{c}}$ & $76.3 \pm 1.93$ & $77.2 \pm 1.82$ & $90.4 \pm 1.81$ & $79.3 \pm 2.02$ \\
\hline $\mathrm{BC}_{1}{ }^{\mathrm{d}}$ & $82.1 \pm 1.62$ & $72.3 \pm 2.11$ & $84.0 \pm 1.81$ & $73.5 \pm 2.51$ \\
\hline \multirow[t]{3}{*}{$P_{2}^{e}$} & $79.3 \pm 2.21$ & $79.3 \pm 2.21$ & $79.3 \pm 2.21$ & $77.5 \pm 2.71$ \\
\hline & \multicolumn{3}{|c|}{$\begin{array}{l}\operatorname{LSD}(0.05)=4.875 \\
\operatorname{LSD}(0.01)=6.577\end{array}$} & \\
\hline & \multicolumn{4}{|c|}{ Number of grains per spike } \\
\hline$P_{1}$ & $40.3 \pm 1.90$ & $40.3 \pm 1.91$ & $40.1 \pm 1.78$ & $38.0 \pm 1.70$ \\
\hline$F_{1}$ & $43.9 \pm 1.81$ & $43.5 \pm 2.20$ & $43.1 \pm 1.72$ & $39.4 \pm 1.52$ \\
\hline $\mathrm{F}_{2}$ & $34.3 \pm 1.61$ & $37.5 \pm 1.66$ & $41.1 \pm 1.62$ & $37.4 \pm 1.60$ \\
\hline $\mathrm{BC}_{1}$ & $38.0 \pm 1.72$ & $41.4 \pm 1.90$ & $48.7 \pm 1.62$ & $37.8 \pm 2.22$ \\
\hline \multirow[t]{3}{*}{$\mathrm{P}_{2}$} & $38.0 \pm 1.70$ & $38.0 \pm 1.70$ & $38.0 \pm 1.70$ & $37.9 \pm 2.10$ \\
\hline & \multicolumn{3}{|c|}{$\begin{array}{l}\operatorname{LSD}(0.05)=6.763 \\
\operatorname{LSD}(0.01)=9.125\end{array}$} & \\
\hline & \multicolumn{4}{|c|}{ Grain weight per spike (g) } \\
\hline$P_{1}$ & $1.82 \pm 0.09$ & $1.82 \pm 0.09$ & $1.78 \pm 0.09$ & $1.51 \pm 0.09$ \\
\hline $\mathrm{F}_{1}$ & $1.75 \pm 0.09$ & $1.75 \pm 0.11$ & $2.00 \pm 0.11$ & $1.71 \pm 0.08$ \\
\hline $\mathrm{F}_{2}$ & $1.52 \pm 0.07$ & $1.61 \pm 0.09$ & $1.75 \pm 0.15$ & $1.46 \pm 0.08$ \\
\hline $\mathrm{BC}_{1}$ & $1.61 \pm 0.09$ & $1.84 \pm 0.11$ & $1.69 \pm 0.09$ & $1.61 \pm 0.09$ \\
\hline \multirow[t]{3}{*}{$\mathrm{P}_{2}$} & $1.51 \pm 0.09$ & $1.51 \pm 0.09$ & $1.51 \pm 0.09$ & $1.49 \pm 0.09$ \\
\hline & \multicolumn{3}{|c|}{$\begin{array}{l}\operatorname{LSD}(0.05)=0.370 \\
\operatorname{LSD}(0.01)=0.500\end{array}$} & \\
\hline & \multicolumn{4}{|c|}{ Spike length $(\mathrm{cm})$} \\
\hline$P_{1}$ & $8.9 \pm 0.25$ & $8.9 \pm 0.25$ & $9.2 \pm 0.26$ & $9.5 \pm 0.27$ \\
\hline $\mathrm{F}_{1}$ & $10.7 \pm 0.28$ & $10.6 \pm 0.29$ & $9.7 \pm 0.22$ & $11.1 \pm 0.21$ \\
\hline $\mathrm{F}_{2}$ & $9.5 \pm 0.22$ & $9.8 \pm 0.29$ & $10.4 \pm 0.22$ & $11.1 \pm 0.25$ \\
\hline $\mathrm{BC}_{1}$ & $10.1 \pm 0.29$ & $10.4 \pm 0.27$ & $10.2 \pm 0.28$ & $10.6 \pm 0.24$ \\
\hline \multirow[t]{2}{*}{$P_{2}$} & $9.5 \pm 0.27$ & $9.5 \pm 0.27$ & $9.5 \pm 0.27$ & $10.2 \pm 0.22$ \\
\hline & \multicolumn{3}{|c|}{$\begin{array}{l}\operatorname{LSD}(0.05)=0.699 \\
\operatorname{LSD}(0.01)=0.945\end{array}$} & \\
\hline
\end{tabular}

${ }^{a} P_{1}$ : First parental line, ${ }^{b} F_{1}$ : First filial generations, ${ }^{C} F_{2}$ : Second filial generations, ${ }^{\mathrm{d}} \mathrm{BC}_{1}$ : First backcross generations, ${ }^{e} \mathrm{P}_{2}$ : Parental inbred lines, 'SE: Standard error

Pesma $(1.46 \mathrm{~g})$. Regarding to the trait spike length the greatest value was observed in the first and second filial generations $\left(\mathrm{F}_{1}, \mathrm{~F}_{2}\right)$ in cross combination Partizanka/ Pesma $(11.1 \mathrm{~cm})$, while the lowest value was observed in the second filial generation $\left(\mathrm{F}_{2}\right)$ in cross combination Pobeda/Partizanka $(9.5 \mathrm{~cm})$, Table 2. The differences among analyzed generations were sufficient to perform generation mean analysis. The results of applying an additive-dominance model with three-parameter revealed that both additive (d) and dominance effects (h) were involved in the inheritance of most traits. In most crosses the dominance effects were greater than additive gene effects. The adequacy of the additive-dominance model with three-parameter was tested using Scaling test and Joint-scaling $\left(\chi^{2}\right)$ test. The results showed that none of the Scaling (one or more scales in A, B and C) or Jointscaling test were significant for the trait plant height in the cross combination Renesansa/Partizanka and also for the trait grain weight per spike in cross combination Sara/Partizanka. For the remaining cross combinations the significant Scaling tests (one or more scales in A, B and C) and Joint-scaling test indicated the presence of non-allelic gene interaction and showed that the three-parameter additive-dominance model does not provide an adequate description of genetic control in the inheritance of the most studied traits (Table 3 ).

Considering that epistasis is important in the inheritance of a trait, the six-parameter model was applied in order to assess the digenic types of interaction which controls the genetic variations for this traits. The estimates of the six parameters, i.e. means (m), additive (d), dominance $(\mathrm{h})$, additive $\times$ additive (i), additive $\times$ dominance (j) and dominance $\times$ dominance (I) are presented in Table 4 .

The six-parameter model revealed that both additive (d) and non-additive (h) genetic effects were found to play a significant role in the inheritance of the examined traits in most cases. Moreover, the relative magnitudes of dominance (h) gene effects were considerably higher compared to additive (d) gene effects for the trait plant height (Table 4).

The results of applying six-parameter model showed that none of the (h), (i), (j) or (l) parameters were significant for the two crosses, involving Partizanka and Pesma as a parental lines, for the traits grain weight per spike and grain number per spike. Also, the six-parameter digenic model does not detect any significant non-allelic interaction effects in the cross combination Sara/Partizanka for the trait grain weight per spike. In the remaining crossing combinations, using the six-parameter model, the presence of significant epistatic effects was confirmed. The type of nonallelic interaction varied from one cross to another and in most of the crosses additive $\times$ additive (i) and dominance $\times$ dominance (l) type of non-allelic interaction was observed. Moreover, significant additive $\times$ additive (i) interaction effects were seen in eleven crosses and the significant dominance $\times$ dominance (l) interaction effects were observed in seven of the 16 crosses examined. Duplicate type of epistasis was also detected for six crosses in which estimates for dominance (h) and dominance $\times$ dominance (l) effects had significant values with opposite signs. Moreover, duplicate gene interactions were seen functioning in controlling each trait in crosses which involved Renesansa and Partizanka as parental lines, as in crosses Pobeda/Partizanka and Partizanka/Pesma for the trait plant height (Table 4). 
Table 3: The estimates of gene effects for the grain yield components using the three-parameter model in four winter wheat crosses

\begin{tabular}{|c|c|c|c|c|}
\hline \multicolumn{5}{|c|}{ Plant height } \\
\hline \multicolumn{5}{|c|}{ Cross combination } \\
\hline & $\begin{array}{c}\text { Pobeda/ } \\
\text { partizanka }\end{array}$ & $\begin{array}{c}\text { Renesansa/ } \\
\text { partizanka }\end{array}$ & $\begin{array}{c}\text { Sara/ } \\
\text { partizanka }\end{array}$ & $\begin{array}{c}\text { Partizanka/ } \\
\text { pesma }\end{array}$ \\
\hline \multicolumn{5}{|l|}{ Gene effect } \\
\hline$m^{a}$ & 78.11 & 77.61 & 82.05 & 76.47 \\
\hline$d^{b}$ & 1.84 & 0.85 & 1.53 & -1.03 \\
\hline$h^{c}$ & 3.97 & -4.32 & 0.84 & 4.68 \\
\hline \multicolumn{5}{|l|}{ Scaling test } \\
\hline$A$ & $12.37^{* *}$ & -7.37 & $15.58^{\star *}$ & $-16.96^{*}$ \\
\hline B & 7.34 & -9.57 & $10.98^{*}$ & $-15.08^{*}$ \\
\hline C & -3.42 & 2.87 & $52.62^{\star *}$ & -8.67 \\
\hline$\chi^{2}(3)$ & $19.32^{\star *}$ & 7.79 & $65.79^{\star *}$ & $16.85^{\star *}$ \\
\hline Probability & $<0.01$ & $>0.05$ & $<0.01$ & $<0.01$ \\
\hline \multicolumn{5}{|c|}{ Number of grains per spike } \\
\hline \multicolumn{5}{|l|}{ Gene effect } \\
\hline $\mathrm{m}$ & 35.41 & 38.67 & 35.58 & 36.17 \\
\hline$d$ & -1.86 & -0.81 & -1.76 & 1.34 \\
\hline $\mathrm{h}$ & 6.24 & 3.90 & 4.94 & 3.11 \\
\hline \multicolumn{5}{|l|}{ Scaling test } \\
\hline$A$ & $-8.25^{\star}$ & -0.94 & $-13.41^{* *}$ & 1.28 \\
\hline B & -2.84 & 1.37 & $-8.10^{*}$ & -1.83 \\
\hline C & $-25.59^{* *}$ & $-15.48^{*}$ & $-17.90^{\star *}$ & -2.12 \\
\hline$\chi^{2}(3)$ & $36.27^{\star *}$ & $10.91^{*}$ & $25.21^{* *}$ & 0.56 \\
\hline Probability & $<0.01$ & $<0.01$ & $<0.01$ & $>0.05$ \\
\hline \multicolumn{5}{|c|}{ Grain weight per spike } \\
\hline \multicolumn{5}{|l|}{ Gene effect } \\
\hline $\mathrm{m}$ & 1.63 & 1.65 & 1.57 & 1.46 \\
\hline$d$ & -0.13 & -0.15 & -0.06 & -0.02 \\
\hline $\mathrm{h}$ & 0.02 & 0.09 & 0.31 & 0.18 \\
\hline \multicolumn{5}{|l|}{ Scaling test } \\
\hline$A$ & $0.34^{*}$ & 0.11 & -0.40 & -0.08 \\
\hline B & 0.03 & $0.44^{*}$ & -0.13 & -0.06 \\
\hline C & $0.75^{\star *}$ & -0.40 & -0.60 & $-0.57^{*}$ \\
\hline$\chi^{2}(3)$ & $13.74^{\star *}$ & $13.14^{\star *}$ & 5.15 & $9.31^{*}$ \\
\hline Probability & $<0.01$ & $<0.01$ & $>0.01$ & $>0.01$ \\
\hline \multicolumn{5}{|c|}{ Spike length } \\
\hline \multicolumn{5}{|l|}{ Gene effect } \\
\hline $\mathrm{m}$ & 9.42 & 9.26 & 9.94 & 9.91 \\
\hline$d$ & 0.53 & 0.27 & 0.37 & -0.26 \\
\hline $\mathrm{h}$ & 0.98 & 1.47 & 0.18 & 1.45 \\
\hline \multicolumn{5}{|l|}{ Scaling test } \\
\hline A & 0.52 & $1.20^{*}$ & $1.16^{*}$ & -0.07 \\
\hline B & -0.69 & 0.61 & 0.18 & 0.56 \\
\hline C & $-2.39^{\star \star}$ & -0.36 & $3.79^{* *}$ & $2.43^{\star *}$ \\
\hline$\chi^{2}(3)$ & $19.76^{\star *}$ & $10.68^{*}$ & $37.06^{\star *}$ & $14.74^{* *}$ \\
\hline Probability & $<0.01$ & $>0.01$ & $<0.01$ & $<0.01$ \\
\hline
\end{tabular}

${ }^{a} \mathrm{~m}$ : Mean, ${ }^{\mathrm{b}} \mathrm{d}$ : Additive effect, ${ }^{\mathrm{c}} \mathrm{h}$ : Dominance effect, ${ }^{*}$ Significant at 0.05 , ${ }^{* *}$ Significant at 0.01

\section{DISCUSSION}

The presented results revealed that an additive-dominance model with three-parameter could not fully explain the inheritance of the investigated traits for many crosses.
Table 4: The estimates of gene effects for the grain yield components using the six-parameter model in four winter wheat crosses

\begin{tabular}{|c|c|c|c|c|}
\hline \multicolumn{5}{|c|}{ Plant height } \\
\hline \multicolumn{5}{|c|}{ Cross combination } \\
\hline & $\begin{array}{l}\text { Pobeda/ } \\
\text { partizanka }\end{array}$ & $\begin{array}{l}\text { Renesansa/ } \\
\text { partizanka }\end{array}$ & $\begin{array}{c}\text { Sara/ } \\
\text { partizanka }\end{array}$ & $\begin{array}{c}\text { Partizanka/ } \\
\text { pesma }\end{array}$ \\
\hline \multicolumn{5}{|c|}{ Gene effect } \\
\hline$m^{a}$ & $53.69^{* *}$ & $98.05^{\star *}$ & $103.10^{* *}$ & $101.77^{\star \star}$ \\
\hline$d^{b}$ & -2.51 & -1.10 & -2.30 & 0.94 \\
\hline$h^{c}$ & $66.73^{\star *}$ & $-60.04^{\star *}$ & -24.88 & $-72.61^{\star *}$ \\
\hline $\mathrm{i}^{\mathrm{d}}$ & $23.13^{*}$ & $-19.81^{*}$ & $-26.05^{\star *}$ & $-23.37^{*}$ \\
\hline$j^{e}$ & 5.02 & 2.21 & 4.60 & -1.89 \\
\hline $\mathrm{I}^{\dagger}$ & $-42.84^{\star *}$ & $36.75^{*}$ & -0.51 & $55.41^{* *}$ \\
\hline \multicolumn{5}{|c|}{ Number of grains per spike } \\
\hline \multicolumn{5}{|c|}{ Gene effect } \\
\hline $\mathrm{m}$ & $23.04^{* *}$ & $23.21^{\star *}$ & $41.11^{\star *}$ & $34.81^{* *}$ \\
\hline$d$ & $2.71^{*}$ & 1.15 & $2.65^{\star}$ & -1.56 \\
\hline $\mathrm{h}$ & 24.29 & $36.65^{\star *}$ & -22.08 & 5.65 \\
\hline i & $14.50^{*}$ & $15.89^{* *}$ & -3.61 & 1.58 \\
\hline j & -5.41 & -2.30 & -5.31 & 3.11 \\
\hline I & -3.41 & $-16.34^{*}$ & $25.12^{*}$ & -1.04 \\
\hline \multicolumn{5}{|c|}{ Grain weight per spike } \\
\hline \multicolumn{5}{|c|}{ Gene effect } \\
\hline m & $1.28^{* *}$ & $0.70^{*}$ & $1.58^{\star \star}$ & $1.07^{\star *}$ \\
\hline d & $0.16^{*}$ & $0.18^{*}$ & 0.14 & 0.01 \\
\hline $\mathrm{h}$ & 0.48 & $2.54^{* *}$ & -0.04 & 0.94 \\
\hline i & $0.56^{*}$ & $0.95^{\star *}$ & 0.07 & 0.43 \\
\hline j & -0.11 & -0.33 & -0.27 & -0.02 \\
\hline I & -0.02 & $-1.50^{* *}$ & 0.46 & -0.30 \\
\hline \multicolumn{5}{|c|}{ Spike length } \\
\hline \multicolumn{5}{|c|}{ Gene effect } \\
\hline $\mathrm{m}$ & $7.33^{\star *}$ & $7.07^{\star *}$ & $12.11^{\star *}$ & $11.79^{* *}$ \\
\hline d & $-0.61^{\star *}$ & $-0.30^{*}$ & $-0.49^{*}$ & $0.31^{*}$ \\
\hline $\mathrm{h}$ & $5.43^{*}$ & $7.54^{\star *}$ & -3.50 & -2.20 \\
\hline $\mathrm{i}$ & $2.22^{*}$ & $2.17^{\star}$ & $-2.44^{* *}$ & $-1.95^{*}$ \\
\hline j & 1.22 & 0.59 & 0.98 & -0.63 \\
\hline I & -2.05 & $-3.98^{\star *}$ & 1.09 & 1.46 \\
\hline
\end{tabular}

am: Mean, ${ }^{b} d$ : Additive effect, ch: Dominance effect, di: Additivexadditive type gene interaction, ej: Additivexdominance type gene interaction, fl: Dominancexdominance type gene interaction, ${ }^{*}$ Significant at 0.05 , ${ }^{* *}$ Significant at 0.01

According to Mather and Jinks (1982) significant results of Scaling or Joint-scaling tests indicate inadequacy of the additive-dominance model to explain the gene effects involved in plant materials and contributions of epistatic effects are important in the inheritance of these traits. Using the six-parameter model the presence of significant epistatic effects was observed in the most crossing combinations which were varied from one cross to another and revealed that individual crosses greatly differed for the gene action on an overall basis.

\section{Plant height}

In controlling inheritance for the trait plant height, the additive-dominance model with three-parameter revealed that dominance effects (h) showed higher values than the 
additive effects (d) indicating that dominance gene effects play the major role in controlling the genetic variation of the plant height for all crosses. The results of Scaling and Chi-square $\left(\chi^{2}\right)$ test showed that three-parameter model was sufficient to explain genetic variation for the plant height for cross combination Renesansa/Partizanka, indicated the absence of non-allelic interactions. Since these tests were significant or highly significant in the remaining three crosses (Pobeda/Partizanka, Sara/Partizanka and Partizanka/Pesma) it became clear that three-parameter model were not suitable for desired trait and indicated the presence of non-allelic gene interaction in the inheritance of the plant height. Using the six-parameter model the significant role of dominance gene effects (h) for all crosses was confirmed, as they had significant and higher values than the additive gene effects (d). The greater value of dominance effects $(\mathrm{h})$ in comparison with additive effects (d) can arise if there is dispersion of genes in the parents which are responsible for reduced estimation of additive component (d) in relation to dominance component $(\mathrm{h})$. The importance of dominance effects in controlling of the plant height were reported by Fethi and Mohamed (2010) and Abassi et al. (2014). However, Farooq et al. (2010), Tonk et al. (2011) and Abedi et al. (2015) reported that additive gene effects were more important in the inheritance of the plant height. Using the six-parameter model, the presence of significant epistatic effects was confirmed in all cross combinations. The significant epistatic effects which were observed were additive $\times$ additive (i) and dominance $\times$ dominance (l). In the cross combinations: Pobeda/Partizanka, Renesansa/Partizanka and Partizanka/ Pesma, it was observed that highly significant dominant gene effect (h), significant epistatic effects additive $\times$ additive (i) and dominance $\times$ dominance (l) contributed significantly to the inheritance of plant height. In these three crosses, the dominance gene effects $(\mathrm{h})$ and dominance $\times$ dominance epistatic effects (l) were in the opposite direction, suggesting that duplicate type of epistasis has occurred, indicating predominantly dispersed alleles at the interacting loci (Jinks and Jones, 1958). The presence of duplicate dominant epistasis in the expression of trait would limit the range of variability and success of the selection and would be affected negatively by these interactions. These results are in agreement with those obtained by Fatehi et al. (2008) and Khattab et al. (2010), who also observed the presence of duplicate type of epistasis in the inheritance of plant height. Contrary to these results, the presence of non-allelic gene interaction caused by complementary genes was indicated Novoselović et al. (2004). In the cross combination Pobeda/Partizanka, the less favorable case of duplicate type of epistasis was observed, as the value of epistatic effects dominance $\times$ dominance (l) was negative. This causes the reduction of the effects of dominant gene and decreasing phenotypic expression of the trait.
Considering the fact that in these crosses, the segregating generations did not follow a simple Mendelian inheritance, high selection pressure is expected in later segregating generations due to possible successful exploitation of additive and dominance components. These results are less favorable for breeders, than if the values of dominance $\times$ dominance epistatic effects (l) were positive, as in the crosses Renesansa/Partizanka and Partizanka/ Pesma. In these crosses epistatic effect in lesser amounts masked the phenotypic expression of the trait. Moreover, genetic effect that can be fixed (additive) was not significant. The reported significant epistatic effects additive $\times$ additive (i) in all crosses could be a result of some preferred interaction between the genes which are controlling this trait. Significant epistatic effects additive $\times$ additive (i) increase the ability to successfully selection more superior genotypes. However, the presence of the additive $\times$ additive type of non-allelic interaction (i) and duplicate type of epistasis seen in this trait, suggest the possibilities of obtaining transgressive segregants in later generations. In the cross combination Sara/Partizanka only epistasis additive $\times$ additive (i) significantly controlled the inheritance of the plant height and additionally drew gene effects in the direction of the additivity. Therefore, it is possible to fix the additive $\times$ additive effect (i) selection in early segregating generations could be fruitful in order to increase the plant height.

\section{Number of grains per spike}

For the trait number of grains per spike, the additivedominance model with three parameters revealed that dominance effects (h) were found to be greater than the additive effects (d), indicating that dominance gene effects play a major role in controlling the genetic variation of this trait. The results of Scaling and Chi-square $\left(\chi^{2}\right)$ test showed that the three-parameter model was sufficient to explain genetic variation for the number of grain per spike for the cross combination Partizanka/Pesma and indicated the absence of non-allelic interactions. It means that in this cross epistasis did not make a significant contribution to the differences among the generation means. In the remaining three crosses (Pobeda/Partizanka, Renesans/ Partizanka and Sara/Partizanka) these tests were significant or highly significant which was indicated by the presence of non-allelic gene interaction and revealed that threeparameter model does not provide an adequate description of genetic control in the inheritance of this trait. Using the six-parameter model, the presence of epistasis was confirmed as well as the fact that individual crosses greatly differed for the gene action. The mean effect (m) was high for all the studied crosses and it indicated that this trait was quantitatively inherited. The additive genetic components were significantly involved in the inheritance of number grains per spike in the cross combination Pobeda/ 
Partizanka, as it was found that additive gene effect (d) and epistatic effect additive $\times$ additive (i) were positive and significant. Additive components could be exploited in a breeding program, as well as significant and positive value of epistatic effect additive $\times$ additive (i) which can be fixed by selection to increase the number of grains per spike and favors the selection in early segregating generation. In the cross combination Renesansa/Partizanka, dominance gene effect (h), epistatic effects additive $\times$ additive (i) and dominance $\times$ dominance (l) were found to be significant. Since dominance gene effects (h) and epistatic effect dominance $\times$ dominance (l) were significant and in opposite sign, duplicate type of epistasis was also detected in the inheritance of this character. Considering the fact that the presence of duplicate dominant epistasis in the expression of this trait would limit the range of variability, selections in early segregating generations are not fruitful and have a breeding importance in later generations. Duplicate type of epistasis in the inheritance of the number of grains per spike has been also reported by Akhtar and Chowdhry (2006), Erkul et al. (2010) and Ijaz and Kashif (2013). In the cross combination Sara/Partizanka additive effects (d) and epistatic effect dominance $\times$ dominance (l) were significant. Because of the additive and epistatic gene effects, it was suggested that selection for greater number of grains per spike should be done in early generations. In the cross combination Partizanka/Pesma only the mean effect (m) was high and significant. It means that none of gene effect or non-allelic interaction seems to be significant for number of grains per spike in this cross. Since the presence of epistasis complicated procedures for improving quality of traits, in this cross combination, the absence of significant epistatic effects greatly simplifies the selection for this trait.

\section{Grain weight per spike}

In controlling inheritance for the grain weight per spike, the additive-dominance model with three parameters revealed that both additive (d) and dominance gene effects (h) were important. Scaling and Chi-square $\left(\chi^{2}\right)$ test showed that the three-parameter model was sufficient to explain genetic variation for the cross combination Sara/ Partizanka, while in the remaining crosses this model failed and was inadequate to explain the genetic variation in the inheritance of this trait. The six-parameter model was fit to explain the genetic variation for the grain weight per spike and confirmed the presence of significant epistatic effects in two crosses: Pobeda/Partizanka and Renesansa/ Partizanka. In the remaining two crosses (Sara/Partizanka and Partizanka/Pesma) no significant gene effect or nonallelic interaction was found. This indicated that for this trait epistasis, did not make a significant contribution to the differences among the generation means. Considering the fact that the presence of epistasis complicated procedures for improving of traits, their absences greatly simplifies the selection for this trait. The absence of epistatic effects in the inheritance of grain weight per spike has been revealed by Garole and Monpara (2005) and Munir et al. (2007). The inheritance of the grain weight per spike differed depending on cross combination and it was controlled by additive and non-additive gene effects. The high value of mean effect $(\mathrm{m})$ was observed for all the studied crosses and indicated that this trait was quantitatively inherited. In the cross combination Pobeda/Partizanka, additive gene effect (d) and epistatic effect additive $\times$ additive (i) were found to be significant. Considering the fact that these components could be fixed by selection and exploited in a breeding program, selection in early generation could be effective for this trait. The presence of significant epistatic effects additive $\times$ additive (i) is favorable for breeders as these effects increase the ability to successfully selection superior genotypes and additionally draw gene effects in the direction to the additivity. The importance of additive effects in the inheritance of the grain weight per spike was also reported by Zaaza et al. (2012) and Abedi et al. (2015). In the cross combination Renesansa/Partizanka, it was observed that both additive (d) and dominance gene effects (h) were significant and important in controlling the genetic variation of the grain weight. A significant role of both additive (h) and dominance gene effects (h) in the inheritance of the grain weight per spike was also reported by Dvojković et al. (2010). The types of non-allelic gene interactions observed in this cross were additive $\times$ additive (i) and dominance $\times$ dominance (l). The dominance $(\mathrm{h})$ and dominance $\times$ dominance (l) effects were in the opposite direction, suggesting that there is a duplicate type of epistasis for this trait. The use of this type of epistatic effects is quite difficult to exploit in wheat breeding programs. Owing to the fact that epistatic effects dominance $\times$ dominance (l) had negative value, which causes decreasing phenotypic expression in the trait, it is expected to obtain less grain weight per spike in infinity generations. In other words, the success of the selection would be affected negatively by these interactions and improvement of this trait needs intensive selection through later generations and could be much slower in a selection program. Duplicate epistasis in the inheritance grain weight per spike has been also reported by Dvojković et al. (2010) and Zaaza et al. (2012).

\section{Spike length}

With regard to the trait of the spike length, the additivedominance model with three parameters revealed that in three crosses dominance gene effects (h) were greater than additive gene effects (d) indicating that dominance gene effects play a major role in controlling the genetic variation of this trait for these crosses. Since the results of Scaling and Chi-square $\left(\chi^{2}\right)$ test were significant or 
highly significant, it became clear that three-parameter model was not suitable for this trait and indicated the presence of non-allelic gene interaction. The six-parameter model was fitt to explain genetic variation for the spike length and confirmed the presence of significant epistatic effects in all cross combinations. It was observed that the inheritance of the spike length differed depending on cross combination and it was controlled by additive and non-additive gene effects. The mean value (m) was highly significant for all the studied crosses which indicated that this trait was quantitatively inherited. The majority of crosses were largely influenced by additive $\times$ additive epistatic effects (i). These findings correspond with the results published by Abbasi et al. (2014). The importance of additive $\times$ dominance $(j)$ and dominance $\times$ dominance epistatic effects (l) was pointed out by Tonk et al. (2011). In the cross combination Pobeda/Partizanka, it was observed that both gene effects, additive (d) and dominance (h), as well as epistatic effect additive $\times$ additive (i), made the major contributions to the inheritance of spike length, as they expressed the high significance. The significant and positive value of epistatic effects additive $\times$ additive (i) indicated that this trait had increased gene and additionally drew gene effects in the direction of the additivity. It is suggested that selection for the development of this trait in early segregating generations would be effective. The cross combination Renesansa/Partizanka was influenced by additive (d) and dominance gene effects (h), as well as by epistatic effects additive $\times$ additive (i) and dominance $\times$ dominance (l). Given that significant dominance gene effects (h) and significant epistatic effect dominance $\times$ dominance (l) were in opposite sign, the presence of duplicate type of non-allelic interaction was confirmed. As the signs of the value of epistatic effects dominance $\times$ dominance (l) were negative, the less favorable case of duplicate type of epistasis was observed, which causes decreasing phenotypic expression in the trait and would be affected negatively by these interactions. Considering the fact that duplicate epistasis might restrict the expression and limit the range of variability, the selection of trait in early segregating generations would not be fruitful. The presence of significant epistatic effects additive $\times$ additive in these crosses is more favorable for breeders (i) as these effects additionally draw gene effects in the direction of the additivity and increase the ability to successfully selection superior genotypes. However, the additive $\times$ additive (i) type of non-allelic interaction and duplicate epistasis seen in this trait suggest the possibilities of obtaining transgressive segregants in later generations. These findings correspond with the results published by other authors who also observed the significance of duplicate type of epistasis in the inheritance of spike length (Akhtar and Chowdhry, 2006; Fatehi et al., 2008; Sharma et al., 2012). The inheritance of spike length in the crosses
Sara/Partizanka and Partizanka/Pesma is controlled by additive type of gene action (h) and epistatic effect additive $\times$ additive (i). As these components are fixable and can be exploited effectively for the improvement of the trait, this indicated that the selection for this trait in early segregating generations would be effective.

\section{CONCLUSION}

Based on the present findings it can be concluded that the investigated traits in this study have shown complex genetic behavior. Although the generation mean analysis revealed that individual crosses greatly differed for the gene action on an overall basis, in most cases the variation in generation means fitted a digenic epistatic model, which implies that improving some of the traits would be moderately difficult. Based on the evaluated genetic parameters it can be concluded that:

In the cross combination Pobeda/Partizanka, the selection in early generations could be recommended for the improvement of the following traits: number of grains per spike, grain weight per spike and spike length, while selection in advanced generations could be effective for the trait - plant height of the wheat. In the cross combination Renesansa/Partizanka, it is suggested that selection for the improvement of all the examined traits should be delayed to later generations of segregation population in wheat. In the cross combination Partizanka/Pesma, selection in early generations might be effective for number of grains per spike, grain weight per spike and spike length, while for the plant height, high selection pressure is expected in later generations. In the cross combination Sara/Partizanka, selection in early generations could be recommended for the plant height, grain weight per spike and spike length, while selection in the further generations might be effective for the number of grains per spike of the wheat.

Therefore, information in this regard would help breeders to select the breeding procedures which can exploit additive as well as non-additive gene effects for improving these traits of wheat yield.

\section{ACNOWLEDGMENTS}

The authors express their appreciation to the Ministry of Education, Science and Technological Development, Republic of Serbia for providing financial support for this research project no. TR 31066.

\section{Author's contributions}

The contribution of all authors was equal in this study. 


\section{REFERENCES}

Abbasi, S., A. Baghizadeh, G. Mohammadi-Nejad and B. Nakhoda. 2014. Genetic analysis of grain yield and its components in bread wheat (Triticum aestivum L.). Annu. Res. Rev. Biol. 4(24): 3636-3644.

Abedi, J., A. Baghizadeh and G. Mohammadi-Nejad. 2015. Genetic analysis for some of morphological traits in bread wheat under drought stress condition using generations mean analysis. J. Stress Physiol. Biochem. 11(2): 40-48.

Akhtar, N. and M. A. Chowdhry. 2006. Genetic analysis of yield and some other quantitative traits in bread wheat. Int. J. Agric. Biol. 8(4): 523-527.

Dvojković, K., G. Drezner, D. Novoselović, A. Lalić, J. Kovačević, D. Babić and M. Barić. 2010. Estimation of some genetic parameters through generation mean analysis in two winter wheat crosses. Period. Biol. 112(3): 247-251.

Erkul, A., A. Unay and C. Konak. 2010. Inheritance of yield and yield components in bread wheat (Triticum aestivum L.) cross. Turk. J. Field Crops. 15(2): 137-140.

Farooq, J., I. Khaliq, A. S. Khan and M. A. Pervez. 2010. Studying the genetic mechanism of some yield contributing traits in wheat (Triticum aestivum L.). Int. J. Agric. Biol. 12: 241-246.

Fatehi, F., M. R. Behamta and A. A. Zali. 2008. Genetic analysis of quantitative traits in wheat (Triticum aestivum). In: Proceedings of "the XI International Wheat Genetics Symposium Proceedings. Edited by Rudi Appels Russell Eastwood Evans Lagudah Peter Langridge Michael Mackay Lynne, Pp. 1-3.

Fethi, B. and E. G. Mohamed. 2010. Epistasis and genotype-byenvironment interaction of grain yield related traits in durum wheat. J. Plant Breed. Crop Sci. 2(2): 24-29.

Foroozanfar, M. and H. Zeynali. 2013. Inheritance of some correlated traits in bread wheat using generation mean analysis. Adv. Crop Sci. 13(6): 436-443.

Garole, A. K. and B. A. Monpara. 2005. Genetics of some important yield determinants in four bread wheat crosses. Nat. J. Plant. Imp. 7(2): 65-68.

Hayman, B. I. 1960. The separation of epistatic from additive and dominance variation in generation means II. Genetica. 31: 133-146.

Kearsy, M. J. and H. S. Pooni. 1996. The genetical analysis of quantitative traits. $1^{\text {st }}$ ed. Chapman and Hall, London, Pp. 46.

Ijaz, U. S. and M. Kashif. 2013. Genetic study of quantitative traits in spring wheat through generation means analysis. Am. Eurasian J. Agric. Environ. Sci. 13(2): 191-197.

Jinks, J. L. and R. M. Jones. 1958. Estimation of the components of heterosis. Genetics. 43: 223-224.

Khattab, S. A. M., R. M. Eemail, A. El-Rahman and M. F. Al-Ansary. 2010. Genetical analysis of some quantitative traits in bread wheat (Triticum aestivum L.). N. Y. Sci. J. 3(11): 152-157.

Kumar, P., R. K. Yadava, B. Gollen and O. P. Sheoran. 2013. Gene effects for different traits of spike morphology in wheat (Triticum aestivum). Indian J. Agric. Sci. 83(7): 748-757.

Ljubičić, N., S. Petrović, M. Dimitrijević and N. Hristov. 2014. Inheritance of the grain number per spike in diallel cross of $5 \times 5$ bread wheat cultivars. Field Vegetable Crops Res. 51(3): 166-169.
Ljubičić, N., S. Petrović, M. Dimitrijević and N. Hristov. 2015. Detection of epistasis for plant height in hexaploid wheat (Triticum aestivum L.) using generation means analysis. In: Proceedings of "the VI International Scientific Agriculture Symposium. Publisher University of East Sarajevo, Faculty of Agriculture, Republic of Srpska, Bosnia, Pp. 488-493.

Mather, K. 1949. Biometrical Genetics. Dover Publication, New York, Pp. 158.

Mather, K. and I. L. Jinks. 1982. Biometrical Genetics. $3^{\text {th }}$ ed. Chapman and Hall, London, Pp. 65-83.

Munir, M., M. A. Chowdhry and M. Ahsan. 2007. Generation means studies in bread wheat under drought conditions. Int. J. Agric. Biol. 9(2): 282-285.

Novoselović, D., M. Barić, G. Drezner, J. Gunjača and A. Lalić. 2004. Quantitative inheritance of some wheat plant traits. Genet. Mol. Biol. 27(1): 92-98.

Ojaghi, J. and E. Akhundova. 2010. Genetic analysis for yield and its components in doubled haploid wheat. Afr. J. Agric. Res. 5(4): 306-315.

OPSTAT Statistical Software. Online Statistical Package for Agricultural Scientists Created by O. P. Sheoran, Computer Programmer at CCS HAU, Hisar, India.

Petrović, S., M. Dimitrijević, N. Ljubičić and B. Banjac. 2012a. Diallel analysis of quantitative traits in wheat crosses. In: Proceedings of the $47^{\text {th }}$ Croatian and $7^{\text {th }}$ International Symposium on Agriculture, Publisher University of Zagreb Faculty of Agriculture, Croatia, Pp. 313-317.

Petrović, S., M. Dimitrijević, S. M. Cimpeanu, D. Bucur, A. A. Gurita, M. Harja, L. Maksimović and M. Belić. 2012b. Spike yield stability in wheat grown under stress conditions of alkaline soil. J. Food Agric. Environ. 10(2): 480-484.

Reynolds, M. P and H. J. Braun. 2013. Achieving yield gains in wheat: Overview. In: Proceedings of the $3^{\text {th }}$ International Workshop of the Wheat Yield Consortium, CENEB, CIMMYT, Cd. Obregon, Sonora, Mexico, D. F., CIMMYT.

Sharma, S. N., R. S. Sain and R. K. Sharma. 2012. Genetics of spike length in durum wheat. Euphytica, 130: 155-161.

Singh, R. P and S. Singh. 1992. Estimation of genetic parameters through generation means analysis in bread wheat. Indian J. Genet. Plant. Breed. 52: 369-375.

Singh, R. P., D. P. Hodson, Y. Jin, E. S. Lagudah, M. A. Ayliffe, S. Bhavani, M. N. Rouse, Z. A. Pretorius, L. J. Szabo, J. Huerta-Espino, B. R. Basnet, C. Lan and M. S. Hovmoller. 2015. Emergence and spread of new races of wheat stem rust fungus: Continued threat to food security and prospects of genetic control. Phytopathology, 105(7): 872-884.

Tonk, A. F., E. Ilker and M. Tosun. 2011. Quantitative inheritance of some wheat agronomics traits. Bulg. J. Agric. Sci. 17(6): 783-788.

Wheat. 2014. Wheat: Vital grain of civilization and food security. In: 2013 Annual Report, CGIAR Research Program on Wheat, CGIAR Research Program on Wheat (WHEAT), Mexico, D.F.

Zaaza, E. I., M. A. Hager and E. El-Hashash. 2012. Genetical analysis of some quantitative traits in wheat using six parameters genetic model. Am. Eurasian J. Agric. Environ. Sci. 12(4): 456-462. 